\title{
Pemahaman komunitas terhadap program community relations di Palimanan dan Citeureup
}

\author{
Feliza Zubair
}

Universitas Padjadjaran, Bandung, Indonesia

\begin{abstract}
ABSTRAK
Community relations dalam konteks Public Relations merupakan implementasi dari tanggung jawab perusahaan terhadap lingkungan sekitar atau pihak-pihak yang terdampak kegiatan perusahaan yang disebut komunitas. Kegiatan yang mutlak perlu dilaksanakan oleh perusahaan khususnya perusahaan pertambangan seperti PT. Indocement Tunggal Prakasa, Tbk., salah satu produsen semen terbesar di Indonesia, yang kerap memberikan dampak kekeringan serta lahan tandus akibat kegiatan penambangan. Sebagai tanggung jawabnya maka perusahaan melakukan revitalisasi lahan bekas galian tambang yaitu pelaksanaan program budidaya tanaman jarak pada lahan pasca tambang. Perusahaan berusaha melihat dari dua sisi kepentingan: yaitu kepentingan perusahaan dan kepentingan komunitas dimana keduanya harus saling mengisi. Namun berkaitan dengan penanganan perusahaan terhadap lahan-lahan bekas galian tambang tersebut, timbul berbagai pemahaman berbeda dari masyarakat baik di Palimanan maupun Citeureup. Permasalahan dalam penelitian ini adalah bagaimana pemahaman komunitas terhadap pelaksanaan program budidaya tanaman Jarak pada lahan bekas galian tambang. Pendekatan penelitian yang digunakan adalah kualitatif, dengan paradigma konstruktivisme, dan jenis studi adalah studi kasus. Subjek penelitian adalah dipilih secara purposif. Pengumpulan data diperoleh melalui wawancara mendalam, observasi langsung, serta analisis dokumen. Hasil dan pembahasan dimana komunitas mempersepsi tanggung jawab perusahaan dalam bentuk materi atau uang (jangka pendek), sedangkan perusahaan mempersepsi tanggung jawab moral dalam upaya memperkecil dampak buruk dan memperbaiki kondisi yang merugikan akibat operasional perusahaan (jangka panjang). Simpulan menunjukkan bahwa pemahaman terjadi berdasarkan pengalaman dan pengetahuan komunitas mengenai situasi serta kondisi yang terjadi pada lingkungan sekitar akibat kegiatan produksi dari perusahaan.
\end{abstract}

Kata-kata Kunci: Community relations; lahan bekas galian tambang; revitalisasi; komunitas; budidaya tanaman jarak

\section{Community understanding of community relations programs in Palimanan and Citeureup \\ ABSTRACT}

Community relations in the context of Public Relations is the implementation of corporate responsibility to the surroundings or parties affected by company activities called the community. Community relations need to be carried out by companies, especially mining companies such as PT. Indocement Tunggal Prakasa, Tbk., One of the largest cement producers in Indonesia, which often gives the effect of drought and barren land due to mining activities. As its responsibility, the company revitalizes ex-mining land, namely the implementation of the Jatropha cultivation program on post-mining land. The company tries to see from two sides of interest: the interests of the company and the interests of the communities where the two must co-exist. However, concerning the company's handling of the ex-mining areas, various understanding arises from the community both in Palimanan and Citeureup. The problem in this research is how the community's understanding of the implementation of Jatropha cultivation programs on ex-mining land. The research approach used is qualitative, with constructivism paradigm, and the type of study is a case study. The research subjects were chosen through purposive sampling method. Data collection techniques applied through in-depth interviews, direct observation, and document analysis. Results and discussion where the community perceives corporate responsibility in the form of material or money (short term), while the company perceives moral responsibility to minimize adverse impacts and improve adverse conditions due to company operations (long term). The conclusion shows that understanding occurs based on community experience and knowledge of the situation and conditions that occur in the environment due to the company's production activities.

Keywords: Community relations; ex-mining land; revitalizes; community; jatropha cultivation

Korespondensi: Dr. Feliza Zubair, M.Si. Universitas Padjadjaran. J1. Raya Bandung Sumedang KM.21, Jatinangor, Jawa Barat 45363. Email: feliza.zubair@unpad.ac.id 


\section{PENDAHULUAN}

Community relations (comrel) merupakan suatu usaha membina interaksi antara perusahaan atau organisasi dengan lingkungan untuk menciptakan saling pengertian dan saling memiliki, perusahaan memahami kebutuhan lingkungannya dan lingkungan juga dapat merasakan manfaat akan keberadaan perusahaan tersebut di wilayah mereka. Selama ini banyak perusahaan yang terganggu keberadaanya akibat perbuatan masyarakat disekitarnya seperti pencurian aset-aset perusahaan, pengerusakan, dan sebagainya. Kondisi ini harus segera ditangani dengan bijaksana oleh pihak perusahaan, salah satumya adalah melakukan komunikasi dan negosiasi melalui kegiatan community relations ini.

Istilah communityrelations merupakan salah satu bentuk kegiatan tanggung jawab perusahaan atau Corporate Social Responsibility (CSR) pada dasarnya menunjukan bahwa hubungan perusahaan dan komunitas tidak dipandang dalam konteks relasi ekonomis saja, melainkan juga dalam bentuk relasi sosial. Kesadaran tentang pentingnya mengimplementasikan corporate social responsibility ini menjadi trend global seiring dengan semakin maraknya kepedulian masyarakat global terhadap produk-produk yang ramah lingkungan dan berdasarkan prinsip-prinsip hak asasi manusia
(HAM) (Siregar, 2016). Community relations atau comrel dilaksanakan secara proaktif oleh berbagai perusahaan di tanah air dan programprogram yang dianggap berhasil adalah yang selaras dengan apa yang dibutuhkan oleh masyarakat ataupun komunitas. Community relations adalah program pengembangan komunitas yang melalui berbagai upaya untuk kemaslahatan bersama bagi organisasi dan komunitas (Devita \& Sumartono, 2010).

Comrel merupakan salah satu bentuk kesadaran perusahaan akan tanggung jawabnya terhadap pengembangan dunia bisnis terutama mewujudkan ekonomi berkelanjutan. Tiga konsep penting yang menjadi fokus dalam kegiatan comrel adalah aspek ekonomi, sosial, dan lingkungan tujuannya adalah mendapat citra dan reputasi yang positif dari komunitas. Komunitas dipahami sebagai sekelompok orang yang memiliki kepentingan terhadap organisasi serta terkait dengan keberadaan organisasi dan secara geografis berada di sekitar organisasi (Grunig \& Hunt, 1984). Dengan memposisikan organisasi adalah mitra bagi komunitas dalam mencapai tujuannya masingmasing melalui sumber-sumber daya dimiliki, semakin menegaskan betapa banyak manfaat yang dipetik organisasi, seperti nama baik, pencapaian tujuan organisasi dan moral kerja karyawan (Hartini, 2016).

Perusahaan dituntut menjadi tetangga 
yang baik, dimana perusahaan tidak saja menyediakan pekerjaan bagi komunitas, membayar pajak tetapi membina komunikasi yang baik dengan komunitas. Bentuk-bentuk relasi diwujudkan dalam program-program bantuan seperti pembangunan sarana jalan, sekolah, rumah ibadah dan bentuk bantuan lain yang dianggap dapat menunjang kemajuan dan potensi ekonomi masyarakat. Berkaitan dengan pengelolaan industri pertambangan, maka perusahaan pertambangan juga tidak terlepas dari tanggung jawab tersebut. CSR merupakan kewajiban asasi perusahaan yang tidak bisa dihindari. Dasar argumentasinya adalah teori akuntabilitas korporasi (corporate accountability theory). Menurut teori ini, perusahaan bertanggungjawab atas semua konsekuensi yang ditimbulkan dari operasional perusahaan (Triyono, 2014).

Berbagai fakta menggambarkan betapa besarnya resiko yang dialami masyarakat sekitar pertambangan, mulai dari limbah tambang yang sangat berbahaya, polusi akibat penambangan, hingga pemanasan global akibat pengolahan industri tambang. Setiap perusahaan pasti memiliki dampak operasi yang dirasakan oleh pemangku kepentingan terutama masyarakat sekitar perusahaan. Oleh karena itu, semakin besar sebuah perusahaan maka dampak operasi perusahaan juga semakin besar sehingga ekspektasi dari pemangku kepentingan terhadap tanggungjawab sosial perusahaan (Siwi, 2017).

Beberapa contoh berbagai kasus pelanggaran yang merugikan komunitas kerap terjadi di area pertambangan khususnya di tanah air. Salah satu kasus yang terjadi adalah 32 orang tenggelam di lubang bekas galian tambang batu bara di Bumi Etam, Kalimantan Timur, 27 orang diantaranya adalah anakanak. Mayoritas warga yang tinggal di sekitar area pertambangan faktanya banyak dirugikan, misalnya amblasnya jalan umum di kelurahan Jawa, Kutai Kartanegara akibat aktivitas salah satu pertambangan besar di Kaltim. Salah satu upaya perusahaan adalah memberikan ganti rugi kepada keluarga korban, namun Komisioner Komisi Perlindungan Anak Indonesia (KPAI) menuntut agar proses hukum tetap berlanjut (Wibisono, 2018). Ada PP No.78/2010 yang berisi tentang kewajiban perusahaan pertambangan untuk melakukan reklamasi pada lahan pascatambang, salah satunya dengan menutup kembali lubang-lubang bekas galian tambang agar tidak berbahaya bagi masyarakat.

Peristiwa tersebut menggambarkan betapa besar risiko yang harus ditanggung oleh masyarakat sekitar lahan pertambangan akibat kecerobohan perusahaan, sementara perusahaan pertambangan merasa sudah cukup memenuhi kebutuhan masyarakat sekitar melalui kegiatan community realations mereka, seperti perbaikan sarana umum, pemberian sembako 
secara berkala dan program charity lainnya, tetapi tanggung jawab yang sebenarnya dalam pemulihan kondisi lingkungan pascatambang (reklamasi) tidak dilakukan. Komunikasi perusahaan yang tidak dilakukan dengan baik pada masyarakat akan berdampak pula pada persepsi masyarakat sekitar yang akan menilai negatif kegiatan yang dilakukan oleh perusahaan. Berbagai program dapat dilakukan untuk meningkatkan nilai aktivitas perusahaan salah satunya melalui strategi dan kebijakan yang dilakukan mengarah pada komunitas (Karmini, 2019).

Dalam konteks Public Relations, community relations merupakan implementasi dari tanggung jawab perusahaan terhadap komunitas, yang mutlak perlu dilaksanakan oleh perusahaan manapun baik formal maupun informal. Perusahaan harus memperhatikan kepentingan bisnis dan hubungan dengan masyarakat pada pelaksanaan community relations (Garriga \& Melé, 2004). Pelaksanaan community relations harus dilihat dari dua sisi kepentingan, yaitu kepentingan perusahaan dan kepentingan komunitas dimana keduanya harus saling mengisi.

Berkaitandenganpelaksananaancommunity relations yang merupakan bagian dari kegiatan CSR berdasar pada ISO 26000, dengan sasaran Sustainabel Development Goals (SDGs) yaitu 17 tujuan isu dunia yang berlaku secara internasional. Implementasi CSR di perusahaan dipengaruhi oleh beberapa faktor, antara lain komitmen pimpinan perusahaan, ukuran dan kematangan perusahaan, regulasi dan sistem perpajakan yang diatur pemerintah. Didalam prakteknya, penerapan CSR disesuaikan dengan kemampuan masing-masing perusahaan dan kebutuhan masyarakat (Yusuf et al., 2020).

Salah satu perusahaan yang menerapkannya adalah PT. Indocement Tunggal Prakasa, Tbk (PT. ITP). Dalam penelitian ini penulis tertarik pada kasus yang terjadi di PT. ITP, dimana perusahaan ini telah memasukkan program revitalisasi dan reklamasi lahan bekas galian sebagai bagian dari tanggung jawab perusahaannya, yaitu di Citeureup Bogor dan Palimanan Cirebon. Kesuburan tanah yang telah dipangkas habis dengan adanya penambangan bahan pembuatan semen yang dilakukan dengan pengeboman, kemudian ditata kembali dan ditanami pohon jarak pagar (Jatropha curcas $L)$. Tanaman ini dibudidayakan di areal bekas tambang karena merupakan salah satu tanaman cocok ditanam di lahan yang tandus. Disamping itu alasan penanaman jarak pagar adalah sebagai upaya pengembangan energi alternatif. Buah jarak yang dihasilkan tersebut diolah dan bisa dipakai dalam proses pembakaran di pabrik PT. ITP.

Dalam program ini, PT. ITP melibatkan masyarakat di sekitar pabrik untuk ikut 
memanfaatkan lahan-lahan pasca tambang dengan menanam tanaman jarak pagar. Perusahaan memberikan bibit tanaman jarak kepada masyarakat serta pendampingan dan bimbingan, agar masyarakat mampu menanam tanaman dengan baik dan hasilnya maksimal. Setelah dipanen, PT. ITP akan membeli hasil tanaman jarak tersebut dari masyarakat sesuai harga pasar. Dengan melibatkan masyarakat setempat dalam proyek ini, maka pihaknya telah memberikan sumbangsih terhadap pembangunan komunitas dan pemberdayaan ekonomi. Disamping itu, penghijauan dengan tanaman jarak dapat mengurangi polusi dan pemanasan global. Salah satu pendekatan dalam proses pemberdayaan adalah melalui pendekatan community empowerment. Melalui pendekatan pemberdayaan ini memberikan peluang kepada masyarakat untuk berperan aktif dalam pembangunan dengan menumbuhkembangkan potensi yang dimilikinya sebagai modal dasar pembangunan, serta memberikan kewenangan penuh kepada masyarakat dalam pengambilan keputusan sesuai dengan keinginan dan kebutuhannya (Haryono et al., 2018).

Berkaitan dengan penanganan perusahaan terhadap lahan-lahan bekas galian tambang, timbul berbagai pemahaman masyarakat terhadap program tersebut. Seperti yang disampaikan bapak MK dari desa Palimanan Barat. Beliau menyampaikan tanggapan dari masyarakat di desanya berkaitan penanaman jarak pagar pada lahan yang sebelum ada penambangan adalah lahan pertanian warga. Beliau menyebutkan bahwa sekarang ini PT. Indocement sudah mempunyai program yang dapat mengurangi polusi dan pemanasan global, dengan menanam pohon Albasia. Bagi perusahaan pertambangan tanggung jawab yang harus dipenuhi adalah memperkecil dampak buruk akibat operasional pabrik, seperti revitalisasi lahan dan reklamasi lahan bekas galian tambang, mengurangi emisi dan mengurangi polusi. Namun, dari realitas di atas tergambarkan adanya perbedaan pemahaman komunitas tentang reklamasi dan rehabilitasi lahan pasca tambang yang dilakukan PT. Indocement Tunggal Prakasa,Tbk. Niat "baik" perusahaan untuk memperbaiki kondisi lahan pasca tambang, mengurangi pemanasan global juga membantu perekonomian masyarakat dipersepsi berbeda oleh komunitas di Palimanan dan komunitas di Citeureup. Pola pemberdayaan ysng diterapkan harus tepat agar dapat mempersatukan masyarakat. Adapun pola pemberdayaan dengan hanya memberi bantuan berupa uang atau bantuan projek kepada masyarakat desa tidak akan merangsang peran serta masyarakat untuk terlibat di dalam pembangunan (Isdarmanto, 2013).

Perbedaan pemahaman komunitas yang terjadi dalam pelaksanaan community 
relations PT. Indocement Tunggal Prakasa, Tbk. berkaitan dengan program budidaya tanaman Jarak Pagar menarik untuk diteliti. Kepedulian terhadap masyarakat sekitar atau relasi komunitas dapat diartikan secara luas, namun secara singkat dapat dimengerti sebagai peningkatan partisipasi dan posisi organisasi di dalanm sebuah komunitas melalui berbagai upaya kemaslahatan bersama bagi organisasi dan komunitas (Suparman, 2013). Adapun permasalahan dalam penelitian ini dapat dirumuskan sebagai berikut yaitu bagaimana pemahaman komunitas terhadap program community relations budidaya tanaman jarak di Palimanan dan Citeureup. Sedangkan tujuan dari penelitian ini adalah (1) Untuk mengetahui pemahaman komunitas di Palimanan terhadap program comrel PT.Indocement Tunggal Prakasa; (2) Untuk mengetahui pemahaman komunitas di Citeureup terhadap program comrel PT.Indocement Tunggal Prakasa; dan (3) Untuk mengetahui penerapan konsep green company yang mendasari program comrel PT Indocement Tunggal Prakasa.

Konsep comrel dalam penelitian ini adalah merupakan salah satu bagian dari konsep CSR yaitu melaksanakan tanggung jawab sosial perusahaan. Communityrelations lebihdimaknai sebagai kegiatan organisasi artinya bukan sekedar komunikasi dalam bentuk pertemuanpertemuan yang tatap muka, namun lebih kepada aksi yang dilakukan bagi lingkungan (Iriantara, 2010). Community relations berhadapan langsung dengan permasalahan sosial yang nyata yang dihadapi komunitas sekitar organisasi. Melalui kegiatan comrel, organisasi bersama-sama dengan komunitas sekitarnya berusaha untuk mengidentifikasi, mencari solusi, dan melaksanakan rencana tindakan atas permasalahan yang dihadapi. PT. ITP melakukan komunikasi yang intens dengan komunitas perusahaan dengan tujuan untuk mengetahui berbagai permasalahan yang terjadi. Hasil dari pertemuan dengan komunitas yang diwakili oleh para kepala desa dan opinion leader kemudian dilakukan identifikasi masalah yang dihadapi komunitas, terutama berkitan dengan dampak-dampak operasional perusahaan, seperti penambangan, pengolahan, dan distribusi. Permasalahan yang mendesak didahulukan dan yang tidak terlalu mendesak dikemudiankan. PT. ITP melihat dari dua sisi kepentingan dan kemanpuan yaitu sisi perusahaan dan komunitasnya dan apabila ada yang perlu diskusikan biasanya dilakukan pertemuan kembali dalam forum yang dinamakan Bilikom.

Community relations adalah program pengembangan komunitas yang melalui berbagai upaya untuk kemaslahatan bersama bagi organisasi dan komunitas (Iriantara, 2010). Pihak perusahaan sebelum membuat program 
comrel perlu melakukan analisis situasi berkaitan kebutuhan komunitas, hal-hal apa yang perlu diperbaiki oleh pihak perusahaan seperti sarana jalan yang rusak akibat kegiatan operasional perusahaan, penyediaan sarana air bersih yang bebas dari limbah buangan perusahaan dan semacamnya. Yang utama adalah kegiatan comrel dapat memberikan "keuntungan" bagi kedua belah pihak, baik pihak perusahaan maupun pihak komunitas. Salah satu yang paling utama dari program budidaya tanaman jarak pagar adalah terpecahkannya beberapa permasalahan lingkungan yaitu, mengurangi pemanasan global, mengurangi polusi, meningkatkan ekonomi komunitas serta membantu penggunaan energi alternatif bagi perusahaan.

Untuk keberhasilan program diperlukan komunikasi dua arah, baik melalui forumforum pertemuan yang formal seperti Bilikom, maupun informal. PT. ITP menjadwalkan pertemuan dengan komunitas secara rutin dan teratur berkaitan penyelesaian masalah-masalah pada komunitas PT. ITP. Dalam setiap program Comrel selalu dilakukan pendampingan guna memperoleh hasil yang maksimal. Pendampingan dilakukan oleh para tenaga ahli, seperti Institut Teknologi Bandung, Universitas Gajah Mada, dan Institut Pertanian Bogor. Setiap pembangunan yang dilakukan oleh pihak manapun harus melibatkan masyarakat dalam pengambilan keputusan, terlebih lagi keputusan yang akan dibuat berhubungan langsung dengan kondisi masyarakat. Dalam hal ini masyarakat diberikan kesempatan untuk mengeluarkan pendapatnya dengan dibukanya forum terbuka (Resdiana \& Widyastuti, 2019).

Berger mengembangkan pemikiran tentang "konstruksi sosial" yang menjelaskan bahwa seseorang dalam kehidupannya mengembangkan suatu perilaku yang repetitif (habits/kebiasaan) (Kuswarno, 2009). Dalam pemikiran Berger dan Luckmann secara aplikatif bahwa seseorang dalam kehidupannya mengembangkan suatu perilaku yang repetitif (Kuswarno, 2009). Perilaku repetitif ini didasari adanyainteraksi diantaraseseorang denganorang lain, sehingga terkonstruksi perilaku seseorang itu. Untuk membuat komunitas melakukan halhal yang "baik" terhadap lingkungan, PT. ITP memerlukan berbagai cara pendekatan dan ini tidak mudah. Kebaikan yang dilakukan satu kali belum tentu menjadi kebiasaan bagi komunitas yang sebelumnya sudah punya cara sendiri. Untuk itu perlu pendekatan dan pelaksanaan yang berulang-ulang agar terbentuk kebiasaan yang diharapkan.

Sejak awal,PT.Indocementtelahmelakukan CSR-nya dalam bentuk bantuan fisik, seperti memperbaiki sarana dan prasarana yang ada di kawasan Citeureup, seperti perbaikan jalan, mesjid, membangun jembatan dan berbagai 
perbaikan lainnya. Juga untuk memperbaiki kondisi ekonomi komunitas perusahaan kemudian melaksanakan berbagai pelatihan sesuai dengan bakat dan minat masing-masing komunitas seperti perbengkelan, pertanian, peternakan dan lain-lain. Prinsip sustainable development yang dilakukan PT. Indocement diwujudkan dalam bentuk program-program yang berkelanjutan untuk masyarakat agar dapat mandiri dimasa sekarang maupun yang akan datang yang disebut "kebiasaan" (habits).

Komunitas Palimanan dan Citeureup mengamati dan merespon program-program community relations yang dilakukan PT. ITP serta berbagai kebiasaan yang diaplikasikan perusahaan seperti mengelola lingkungan berkelanjutan, kepedulian akan energi terbarukan (energy crops), energi tepat guna (biogas), enterpreuneurship, kemudian mereka diarahkan untuk turut terlibat dalam program tersebut. Perusahaan berusaha membangun kesadaran komunitas akan pentingnya menjaga lingkunganyang berkelanjutan dan memperbaiki kehidupan mereka secara ekonomi.

Teori atau aliran etika yang relevan dengan penelitian ini adalah teori Etika Utilitarianisme dimana memiliki relevansi yang kuat untuk diterapkan dalam dunia bisnis atau Public Relations. Dalam aplikasinya teori ini menekankan bahwa sesuatu yang baik adalah yang berguna atau membawa kebaikan bagi banyak orang dan suatu yang buruk adalah yang merugikan banyak orang (Sonny, 1998). Dalam penelitian ini program-program community relations khususnya program budidaya energi alternatif, baik budidaya Jarak Pagar maupun Energy Crops lainnya dilakukan untuk kebaikan sebanyak mungkin orang baik komunitas maupun perusahaan. Karena program-program PT. Indocement Tunggal Prakasa, Tbk. ini ditujukan untuk menciptakan pembangunan berkelanjutan yang dapat bermanfaat bagi semua pihak.

Dalam aplikasinya teori Etika Utilitarianisme ini digunakan sebagai barometer dan standar penilaian. Antara lain dalam proses untuk mengambil sebuah keputusan, kebijaksanaan, dan bertindak dalam mengambil keputusan yang tepat. Berkaitan dengan penelitian ini adalah ketika perusahaan memutuskan pelaksanaan program reklamasi dan revitalisasi lahan pascatambang (marginal) melalui budidaya tanaman Jarak dan energy crops. PT. ITP yakin bahwa program ini akan sangat berguna bagi semua orang.

Etika utilitarianisme dipakai dalam perencanaan comrel khususnya untuk mengatur sasaran dan target yang hendak dicapai, menyangkut kepentingan banyak orang. Semua alternatif yang ada lalu dipilih berdasarkan sejauh mana kemungkinan untuk mendatangkan manfaat terbesar bagi sebanyak mungkin orang. 
Berkaitan dengan program reklamasi dan revitalisasi lahan melalui budidaya tanaman Jarak Pagar dan energy crops maka teori ini digunakan untuk mengukur berapa banyak komunitas dan generasi ke depan yang akan dapat menikmati kehidupan lebih baik jika program ini dijalankan. Relationship Management Theory dikembangkan oleh John Ledingham dan Steven Bruning yang menjelaskan bahwa untuk dapat menyeimbangkan kepentingan organisasi dengan publiknya harus melalui pengelolaan hubungan antara organisasi dan publik. Pendekatan hubungan manajemen terhadap PR berpusat pada dimensi atau parameter sebuah hubungan (Ardianto, 2010).

Pertama-tama program community relations dijalankan untuk membantu memperbaiki lingkungan sosial, memberikan nilai tambah dan kesejahteraan bagi masyarakat sekitar melalui sistem pemberdayaan terpadu. Demikian disampaikan oleh Ibu Anita selaku Head Officer community relations PT. Indocement, di Palimanan, juga oleh Bapak Aditya selaku Head Officer community relations PT. Indocement Citeureup. Program community relations dilaksanakan secara konsisten dan kontinyu, dimulai dari perencanaan yang berdasarkan social mapping dan forum komunikasi dua arah antara masyarakat dengan pihak perusahaan.

Konsep "pemahaman" merupakan suatu istilah yang sering diterjemahkan dalam berbagai persepsi, dalam penelitian ini arti pemahaman merupakan dasar dari penjelasan mengenai persepsi komunitas terhadap kegiatan community relations yang dilaksanakan oleh PT ITP baik di Palimanan maupun Citeureup Bogor. Pemahaman pada hakekatnya merupakan hasil manusia belajar dari lingkungan. Pemahaman ini merupakan rangkaian pengalaman berkaitan pelaksanaan program-program Comrel perusahaan khususnya budidaya tanaman jarak pagar, yang kemudian menimbulkan pengertian pada komunitas tentang "niat baik" perusahaan terhadap lingkungannya.

Berkaitan dengan pemahaman komunitas terhadap kegiatan community relations yang lebih spesifiknya mengenai program budi daya tanaman Jarak pada lahan bekas galian tambang adalah bagaimana komunitas mengerti benar-benar akan keberadaan program ini. Pemahaman terjadi berdasarkan pengalaman dan pengetahuan mereka mengenai situasi serta kondisi yang terjadi pada lingkungan sekitar akibat kegiatan produksi dari perusahaan. Berdasarkan penjelasan mengenai permasalahan di atas, penelitian ini berfokus pada bagaimana pemahaman komunitas terhadap program community relations budidaya tanaman jarak di Palimanan dan Citeureup. 


\section{METODE PENELITIAN}

Metode yang digunakan adalah metode kualitatif dengan pendekatan studi kasus, dilakukan untuk mengeksplorasi dan memahami makna dari sejumlah individu / informan (komunitas) terhadap masalah sosial atau kemanusiaan. Adapun pemahaman akan makna ini dipengaruhi oleh pengalaman dan pengetahuan komunitas itu sendiri. Sebagai metode, studi kasus dipahami sebagai pendekatan untuk mempelajari, menerangkan, atau menginterpretasi suatu kasus dalam konteksnya yang alamiah tanpa adanya intervensi dari pihak luar. Ditegaskan Schramm bahwa diantara ragam semua studi kasus kecenderungan yang paling menonjol adalah upaya untuk menyoroti suatu keputusan atau seperangkat keputusan, yakni mengapa keputusan itu diambil, bagaimana ia terapkan dan apa hasilnya (Salim, 2016).

Melalui pendekatan studi kasus peneliti melakukan pendekatan dari berbagai sisi yang menjadi ciri khas dari studi ini yaitu bagaimana perusahaan memahami kegiatan community relations yang mereka lakukan, dan bagaimana komunitas memahami community relations yang dilakukan oleh perusahaan bagi mereka. Keunikan yang tampak adalah adanya latar belakang budaya komunitas yang mempengaruhi pemahaman mereka terhadap perusahaan, sehingga feedback dan respon yang muncul menjadi spesifik dan unik.

Pendekatan studi kasus adalah menjawab "bagaimana" (how) dan "mengapa" (why) yang digunakan untuk menggali realitas pada penelitian yaitu bagaimana pemahaman komunitas terhadap kegiatan comrel PT. ITP dan mengapa terbentuk pemahaman tersebut (Yin, 2014). Hal ini disebabkan bahwa sebuah kasus bisa sederhana bisa juga rumit, namun perlu penelaahan yang cermat dan pengkajian yang mendalam. Maka dalam penelitian ini peneliti membagi dua pengkajian terhadap operasional pabrik semen PT. Indocement yang berbeda lokasi, yaitu di Citeureup, Bogor dan Palimanan, Cirebon. Dua lokasi yang berbeda memiliki karakteristik masyarakat yang berbeda pula, karena itu meskipun program-program yang di gulirkan sama dalam aplikasinya tidak sama karena perlu disesuaikan dengan situasi dan kondisi masyarakat. Yang memiliki latar belakang budaya berbeda.

Adapun untuk melengkapi penelitian ini penulis mengadakan wawancara mendalam dengan komunitas perusahaan baik anggota Bilikom maupun komunitas lain yang mewakili masyarakat dalam pelaksanakan programprogram community relations perusahaan, baik di Palimanan Cirebon maupun di Citeureup Bogor. Adapun pengambilan sampel pada penelitian dilakukan secara 
purposive, yaitu ditentukan sesuai dengan tujuan studi (Salim, 2016). Maka dalam penelitian ini narasumber adalah komunitas PT. ITP di wilayah Palimanan dan Citeureup yang diwakili oleh anggota-anggota Bilikom dan beberapa tokoh masyarakat, penarikan sampel yang ditentukan sesuai dengan tujuan studi penelitian dengan memenuhi ketetapan sebagai berikut: (1) Subjek penelitian yaitu para pengelola CSR PT. Indocement dan komunitas yang berada sekitar operasional perusahaan di Palimanan dan Citeureup; (2) Para informan yang berkemampuan dan berkemauan untuk mengutarakan pengalaman masa lalu dan masa sekarang berkaitan dengan pererapan CSR PT. Indocement; dan (3) Para Informan yang terlibat langsung dalam program-program CSR PT. Indocement mulai dari perencanaan hingga pelaksanaan, sehingga memiliki pengalaman yang khusus berkaitan dengan penerapan program CSR PT. Indocement, utamanya dalam revitalisasi dan reklamasi lahan bekas galian tambang. Maka, beberapa informan penting diantaranya adalah (1) Bapak SD dari Desa Cupang; (2) Bapak MI dari Desa Gempol; (3) Bapak MK dari Desa Palimanan Barat; (4) Bapak SM dari Desa Walahar; dan (5) Bapak SN dari Desa Kedungbunder.

Adapun teknik penelitian atau teknik pengumpulan data meliputi wawancara mendalam, observasi kualitatif, pengumpulan dokumen serta pengambilan data audio visual (Creswell, 2013). Wawancara dilakukan secara intens dengan para narasumber baik dalam situasi formal maupun informal. Observasi dilakukan pada setiap kesempatan dengan panduan pedoman observasi agar diperoleh hasil yang maksimal dan data yang akurat. Adapun pengambilan foto-foto dan video dilakukan untuk memperkuat data-data yang sudah diperoleh di lapangan. Keabsahan data menggunakan teknik trianggulasi sumber dan data. Trianggulasi dilakukan kepada pihak PT.Indocement Tunggal Prakasa baik di Palimanan maupun di Citeureup yang ikut terlibat dalam perencanaan dan pelaksanaan kegiatan community relations.

\section{HASIL DAN PEMBAHASAN}

Komunitas PT. Indocement Tunggal Prakasa dalam hal ini adalah warga yang berada di sekitar area penambangan atau quary, di sekitar rel-rel pengiriman hasil penambangan (conveyor) dan di lingkungan operasional pabrik di Palimanan Kabupaten Cirebon maupun di Citeureup Kabupaten Bogor. Dari observasi dan wawancara yang dilakukan diperoleh fakta-fakta mengenai langkahlangkah pelaksanaan program comrel budidaya tanaman Jarak Pagar Energy Crops oleh PT. Indocement di Palimanan, yaitu dilakukannya berbagai pelatihan berkaitan penanaman, 
pemeliharaan dan budidaya tanaman-tanamaan energi alternatif. Peserta tidak saja memperoleh pengetahuan secara teknis namun mendapat pula pengetahuan mengenai pentingnya kesadaran akan pengelolaan lingkungan berkelanjutan. Ini adalah usaha membagi nilai-nilai penting bagi peningkatan hidup masyarakat di masa sekarang maupun di masa mendatang. Setelah dianggap cukup paham, maka selanjutnya perusahaan memberikan bibit dan pendampingan secara intensif kepada para peserta pelatihan, sebelum mereka nanti akan dipercaya untuk melakukannya secara mandiri.

Pemahaman komunitas terhadap kegiatan Comrel PT. Indocement Tunggal Prakasa,Tbk adalah bagaimana komunitas mengerti benarbenar akan keberadaan program ini, dan paham sebagai bentuk tanggung jawab sosial perusahaan terhadap lingkungannya. Program revitalisasi lahan pascatambang melalui budidaya tanaman Jarak Pagar merupakan program bersama perusahaan dan komunitas, karena itu komunitas merasa perlu terlibat didalamnya.

Pemahaman terjadi berdasarkan pengalaman dan pengetahuan komunitas mengenai situasi serta kondisi yang terjadi pada lingkungan sekitar akibat kegiatan produksi dari perusahaan, mereka melihat lahan-lahan menjadi marginal akibat penambangan, tandus, dan tidak produktif lagi. Jelas dampak buruk ini sangat merugikan masyarakat sekitar. Namun, dengan dilakukannya program comrel oleh perusahaan, maka lahan-lahan tersebut dapat produktif kembali.

Hasil penelitian menunjukan bahwa program budidaya tanaman jarak merupakan bisnis etis perusahaan, dimana seluruh konteks dalam kegiatan community relations PT. Indocement Tunggal Prakasa,Tbk. yang kait mengkait berkenaan dengan etika bisnis perusahaan pertambangan. Budidaya tanaman Jarak Pagar tidak saja menghasilkan biofluel yang ramah lingkungan sehingga polusi dan emisi berkurang, tetapi sekaligus memfungsikan kembalilahan-lahanpascatambang(revitalisasi) dan menghijaukan kembali lahan-lahan yang tidak produktif dengan reklamasi. Penghijauan ternyata tidak hanya mengurangi $\mathrm{CO}_{2}$ tetapi juga memproduksi kembali hara tanah. Dalam reklamasi dan revitalisasi lahan ditanam juga pohon-pohon yang dapat memperbaiki hara tanah yaitu pohon-pohon keras seperti Jati, Jinjing dan lain-lain. Pengelolaan area pascatambang dilakukan oleh $\mathrm{P} 3 \mathrm{M}$ dengan merekrut tenaga kerja lokal (komunitas) sehingga disamping mendapatkan ilmu dari pelatihan, komunitas juga mendapat insentif. Pengelolaan lahan masuk dalam "lingkungan", pelatihan masuk dalam "sosial” dan perkerjaan/ insentif masuk dalam "ekonomi”.

Keunikan kasus dalam penelitian ini adalah 
berkaitan adanya perbedaan persepsi komunitas PT. ITP di Palimanan dengan komunitas PT. ITP di Citeureup Bagor terhadap kegiatan community relations yang dilaksanakan oleh perusahaan. Ukuran keberhasilan interaksi tampak dari pemahaman yang sama pada komunitas dan perusahaan mengenai penerapan etika bisnis dalam aplikasi kegiatan community relations tersebut. Terutama berkaitan dengan reklamasi budidaya tanaman jarak dan energy crops serta revitalisasi lahan marginal sebagai salah satu bentuk kepedulian perusahaan terhadap lingkungannya. Perbedaan persepsi yang terjadi pada masyarakat akan menghambat pelaksanaan community relations yang idealnya didukung oleh seluruh elemen masyarakat.

Keterlibatan seluruh elemen masyarakat merupakan hal yang penting dalam pelaksanaan program utamanya program community relations. Sebagai bagian dari kegiatan CSR maka kegiatan comrel dapat diterapkan model kemitraan yang melibatkan masyarakat dalam pelaksanaan program community relations, masyarakat akan dapat mengetahui kebutuhan sesuai dengan sumber daya yang ada di lingkungan sekitar dan mencapai kemandirian (Umma et al., 2016). Sejalan dengan pernyataan tersebut yang menjelaskan dalam melaksanakan community relations, perusahaan tidak hanya mempertimbangkan faktor ekonomi saja namun juga dampak pada lingkungan dan elemen masyarakat pendukung operasional perusahaan dalam jangka panjang (Adiati, 2012).

Komunitas PT. ITP di Palimanan sebagian besar adalah petani, mereka hidup sangat bergantung pada lahan pertanian dan perkebunan dengan hasil utama padi dan buah-buahan. Pemahaman komunitas PT. ITP di Palimanan tentang reklamasi budidaya tanaman jarak tampak pada ungkapan salah satu informan yang menyatakan bahwa program telah dilaksanakan dengan baik. Berikut adalah pernyataan MK yang mengatakan bahwa secara pribadi berterimakasih kepada pihak 'PT. Indocement' yang mana telah memperbaiki berbagai fasilitas fisik secara berkesinambungan dan program community relations yang dilakukan oleh PT. Indocement tepat dilakukan dan berdampak positif bagi lingkungan dengan menanam pohon Albasiah yang dapat mengurangi polusi dan pemanasan global. Berdasarkan pernyataan informan di atas, dapat diketahui gambaran bahwa sejauh ini kegiatan community relations PT. Indocement-Palimanan disambut baik oleh komunitas meskipun ada sedikit ganjalan ketika beliau mengatakan menanam pohon Albasiah lebih baik daripada menanam jarak pagar. Berdasarkan pengalaman komunitas, kayu albasiah bisa bermanfaat dalam membuat bangunan atau keperluan lain, seperti meja, kursi, lemari dan alat-alat rumah tangga, namun bila tanaman jarak pagar hanya berguna bagi 
kepentingan produksi perusahaan.

Dibalik respon positif terhadap pelaksanaan program community relations, PT. ITP, sebagian masyarakat Palimanan mengeluhkan bahwa program budidaya tanaman jarak pagar hasilnya tidak sebanding dengan dampak buruk yang dihasilkan dari kegiatan operasional perusahaan utamanya berkaitan dengan penanganan perusahaan terhadap lahanlahan bekas galian tambang. Hal ini diperkuat oleh pernyataan MK yang menyebutkan PT. Indocement sesudah mengeruk kekayaan dari Desa Palimanan Barat dan kompensasinya untuk kami tidak ada maka kami lebih memilih menanam singkon daripada menanam tanaman jarak. Berdasarkan pernyataan tersebut, dapat diketahui jika masyarakat menganggap hal yang penting setelah dilakukan kegiatan operasional perusahaan di lingkungannya adalah bagaimana komunitas dapat mengolah kembali lahanlahan mereka seperti semula, dengan tanaman kebutuhan sehari-hari. Tampaknya pemahaman mereka lebih berorientasi untuk konsumsi langsung. Hal ini karena program Budidaya tanaman jarak pada lahan pascatambang dari pihak perusahaan dirasakan kurang sejalan dengan harapan komunitas.

Peneliti selanjutnya menanyakan apa yang dipahami mengenai tanggung jawab perusahaan terhadap masyarakat Palimanan Barat berkaitan dengan kegiatan comrel PT. Indocement.
Berikut adalah pernyataan informan MK yang menyatakan bahwa masyarakat Palimanan Barat justru lebih dulu ingin minta kejelasan mengenai "uang debu" yaitu dana kompensasi penyumbangan kerugian bagi masyarakat akibat penambangan dan produktifitas PT. Indocement. Uang debu adalah sejumlah dana yang diberikan perusahaan kepada komunitas berkaitan dengan tuntutan masyarakat yang merasa dirugikan dengan adanya polusi debu akibat aktivitas perusahaan di Palimanan. Disini ada perbedaan persepsi tentang tanggung jawab moral oleh perusahaan dan oleh pihak komunitas. Komunitas mempersepsi tanggung jawab dalam bentuk materi atau uang, sedangkan perusahaan mempersepsi tanggung jawab moral dalam upaya memperkecil dampak buruk dan memperbaiki kondisi komunitas serta mempersiapkan masa depan yang lebih baik. Mengubah mindset komunitas yang ingin segala sesuatu lebih mudah dan "instan" merupakan tantangan tersendiri bagi perusahaan. Menentukan suatu kebijakan memerlukan pertimbangan yang sungguh-sungguh. Sebuah kebijakan yang diambil oleh pembuat kebijakan haruslah mengandung konten yang jelas dan konsisten. Kebijakan dengan isi yang jelas akan memudahkan sebuah kebijakan dan akan menghindarkan distorsi atau penyimpangan dalam pengimplementasiannya (Sujarwani et al., 2018). 
Berikutnya peneliti mewawancarai informan bapak SN untuk mengetahui tanggapan dan pemahaman beliau mengenai budidaya tanaman Jarak Pagar di area bekas tambang yang menyatakan bahwa masyarakat sebenarnya belum paham dengan 'Energi Crops' karena sejauh ini penanaman Jarak Pagar khususnya di Desa Kedung Bunder belum maksimal, harga jual tidak sesuai dengan kebutuhan masyarakat desa, jadi lebih baik palawija. Di Kedung Bunder pernah diujicoba tanaman Jarak Pagar pada lahan pertanian warga, namun karena Jarak Pagar itu tidak bisa dikonsumsi langsung dan hanya dijual ke pabrik saja, maka masyarakat merasa rugi, karena bila mereka menanam tanaman yang bisa langsung dikonsumsi akan lebih menguntungkan, seperti tanaman palawija.

Narasumber yang berikutnya adalah ML sebagai Kepala desa Gempol, Kecamatan Gempol, Kabupaten Palimanan Cirebon, beliau menyampaikan bahwa selama ini program budidaya tanaman jarak di daerahnya tidak berhasil. Adapun pernyataan informan adalah sebagai berikut:

"Program Energy Corps ya? Belum jelas bu, mungkin harus ada sosialisasi dari perusahaan. Kalau tanaman Jarak Pagar.... kurang effektif bu, karena hasilnya.. tanaman jarak pagar hanya dijual untuk indocement, rugi! Lebih baik menanam tanaman yang lebih bermanfaat bagi lingkungan dan masyarakat".

Berkaitan dengan program-program community relations yang telah dilakukan oleh perusahaan menurut ML sejauh ini belum memenuhi kebutuhan masyarakat secara maksimal. Hal ini dipertegas dengan pernyataan bahwa program-program yang ada diperbaiki, transparan, kalau ada pengajuan program dari desa sebaiknya segera di realisasi. Sejalan dengan pernyataan tersebut, SM selaku Kepala Desa Walahar, menyampaikan pemahamannya tentang program energy corps, beliau menilai kurang efektif bila dilihat dari sisi ekonomi. Adapun maksud dari pernyataan tersebut adalah yang dibutuhkan warga saat ini adalah tanaman yang dapat dikonsumsi langsung dan dijual langsung. Kalau Jarak Pagar itu perlu pengolahan terlebih dahulu, kalau dijual hasilnya atau buahnya hanya ke PT. ITP.

Meskipun masih jauh dari optimal namun tidak dapat disangkal bahwa PT. ITP telah berusahamengupayakan program-program yang nyata dan membumi berlandaskan itikad baik perusahaan. Warga desa Walahar juga menyadari bahwa program-program community relations perusahaan, seperti pembagian sembako dan perbaikan sarana ibadah, sekolah maupun jalan telah banyak membantu mereka. Berikut adalah pernyataan SM yang menyebutkan ucapan terimakasih atas jasa perusahaan dengan program-program community relations nya selama ini, tetapi selanjutnya mohon dibuat lebih seimbang dengan kerugian yang dialami 
warga. Opinion leader yang berikutnya adalah Kepala Desa Cupang kecamatan Gempol, kabupaten Palimanan Cirebon. Beliau sudah menjadi bagian dari kegiatan-kegiatan PT. Indocement selama 13 tahun. Karena itu beliau yang paling banyak memberikan masukan mengenai berbagai kegiatan community relations $\mathrm{PT}$. Indocemement. Berkaitan dengan budidaya tanaman Jarak pada lahan bekas tambang, CS menjelaskan bahwa untuk di wilayah Cupang tanaman Jarak Pagar sudah pernah ditanam tetapi bukan pada lahan bekas galian melainkan di lahan warga. Beliau hafal dengan berbagai penghargaan yang di raih perusahaan berkaitan dengan program-program community relations perusahaan, tetapi beliau menyayangkan pihak perusahaan yang tidak transparan terutama masalah tender dalam pembangunan infrastruktur, masalah uang debu, dan masalah perekrutan tenaga kerja lokal. Pada akhirnya, Kepala Desa sering dituduh oleh warga memakan hak mereka, padahal dari perusahaan tidak jelas luncuran uang debu itu.Uang debu itu selama ini dipahami warga sebagai bentuk kompensasi dari kerugian komunitas akibat penambangan dan kegiatan produksi perusahaan yang menyebabkan lingkungan mereka terkena polusi debu. Karena itu apapun bentuk kegiatan community relations yang dilakukan perusahaan tetap dianggap belum seimbang, bila kompensasi uang debu tidak diberikan kepada warga.

Menurut CS kegiatan reklamasi untuk Cupang belum ada namun untuk dibeberapa tempat di desa Cupang keadaan tanah amblas $30 \mathrm{~cm}$ akibat pemboman bukit-bukit kapur dan kami mencoba memperbaikinya. Blasting atau peledakan umum dilakukan di pertambanganpertambangan untuk mengambil material bahan baku pembuatan semen. Dilihat dari sifat batu kapur yang menjadi bahan dasar industri semen memiliki karakteristik yang keras, maka salah satu cara penambangannya adalah dengan menggunakan proses peledakan. Menurut MS, peledakan sudah diatur sedemikian rupa agar ada dalam kondisi "aman", artinya tidak mengganggu lingkungan (dalam kapasitas getaran yang wajar), namun warga Cupang mengeluhkan beberapa rumah mengalami keretakan karena getaran "blasting". Dalam penelitian ini PT. ITP sebetulnya memiliki jembatan interaksi dengan komunitas melalui Bilikom, namun tentu tidak semua pemasalahan dapat dibicarakan melalui bilikom, kiranya perlu ada forum pertemuan tersendiri untuk dapat mencapai situasi saling mengerti, saling memahami antara perusahaan dengan komunitas. Kiranya komunitas mengharapkan adanya komunikasi tatap muka, langsung turun ke lapangan bertemu dengan warga serta membuka forum tanya jawab antara pihak pengelola comrel perusahaan dengan warga, 
bukan hanya anggota bilikom saja.

Adapun pemahaman Komunitas PT. Indocement Tunggal Prakasa,Tbk lokasi operasional Citeureup Bogor agak berbeda dengan komunitas di Palimanan. Komunitas PT.ITP di Citeureup Bogor umumnya bukan petani, mereka sebagian besar adalah pedagang yang merantau ke Jakarta dan industri (rumah) serta perbengkelan. Informan SN menyampaikan beberapa harapan warganya yang belum direalisasikan oleh perusahaan, seperti masalah perekrutan tenaga kerja lokal oleh perusahaan yang presentasenya sangat kecil, karena jumlah yang lebih besar didominasi oleh tenaga kerja dari luar. Komunitas atau masyarakat di Citeureup meminta kompensasi uang "debu" kepada PT. ITP tetapi beliau beserta warganya tidak melupakan manfaat dari program community relations perusahaan, seperti sarana prasarana menjadi lebih baik dan adanya pembagian sembako. Informan lainnya S mengatakan bahwa pemahaman tentang kegiatan community relations $\mathrm{PT}$. Indocement khususnya berkaitan dengan budidaya tanaman Jarak Pagar yng dilakukan oleh perusahaan ada di quary sedang program kesehatan, pendidikan, pelatihan bengkel, dan sarana prasarana di desa dibantu oleh PT. Indocement. Selain itu, sebenarnya pihak Desa sangat berterimakasih pada perusahaan yang sudah membantu berbagai fasilitas publik yang berada di Desa
Citeureup. Bahkan saat ini sudah ada budidaya ikan hias dan bengkel motor yang menjadi binaan PT. Indocement.

Sejak awal PT. ITP telah melakukan community relations nya dalam bentuk bantuan fisik, seperti memperbaiki berbagai infrastruktur di kawasan Citeureup, antara lain jalan, mesjid, membangun jembatan dan berbagai perbaikan lainnya. Juga untuk memperbaiki kondisi ekonomi komunitas perusahaan kemudian melaksanakan berbagai pelatihan sesuai dengan bakat dan minat masing-masing komunitas seperti perbengkelan, pertanian, peternakan dan lain-lain. Prinsip Sustainable development yang dilakukan PT. Indocement diwujudkan dalam bentuk program-program yang berkelanjutan untuk masyarakat agar dapat mandiri dimasa sekarang maupun yang akan datang. Adapun mengenai budidaya tanaman jarak pada lahan bekas penambangan tidak terlalu mempengaruhi kehidupan komunitas PT. ITP di Citeureup Bogor.

Wawancara berikutnya adalah $\mathrm{T}$ selaku petugas di Kantor Kepala Desa Bantarjati Kecamatan Klapanunggal yang memberikan keterangan tentang community relations yang dilakukan PT. Indocement dan khususnya tentang budidaya tanaman Jarak Pagar. Adapun pernyataan informan $\mathrm{T}$ yaitu $\mathrm{PT}$. Indocement telah banyak memberikan bantuannya, seperti membangun kantor desa, pelatihan 
bengkel sepeda motor dan pendampingan serta pemberian modal kepada masyarakat Desa Bantarjati. Namun, untuk tanaman Jarak Pagar ada di quary. Wawancara selanjutnya adalah dengan komunitas yang bekerja dengan sistem kontrak di PT. ITP. Informan RZ yang menyatakan pemahamanya tentang budidaya tanaman Jarak Pagar yang dilakukan oleh PT. Indocement:

"Alternatif fluel dan penghijauan. Pelatihan bercocok tanam meskipun dengan kondisi tanah seperti ini, seperti pasir mukti, karena tanah liat, diambil untuk pertambangan. Intinya adalah untuk perbaikan lingkungan berkelanjutan, karena beliau menyadari apa yang dilakukannya sekarang ini kelak akan 'berbuah manis'. Jadi, setelah ditanami ada perubahan ph tanah, jadi yang dimaksud revitalisasi kita menanam pohon-pohon dengan perawatan khusus, otomatis akan berpengaruh kepada tanahnya juga. Haranya juga....".

Wawancara berikutnya dengan YT yang bukan penduduk asli Desa Hambalang, namun beliau sudah 30 tahun menjadi penduduk disana, dan beliau mendapat kesempatan untuk bekerja di P3M oleh PT. Indocement. Beliau mendapat kepercayaan untuk menangani peternakan dan melakukan pelatihan pembuatan biogas dari kotoran sapi.

Ada beberapa hal yang membuat pemahaman komunitas Palimanan berbeda dengan komunitas Citeureup terhadap program yang sama yaitu budidaya tanaman Jarak Pagar Perbedaan itu antara lain: karakteristik masyarakat yang berbeda, aplikasi program yang berbeda, dan cara pandang pengelola yang berbeda. Ditinjau dari sosiopsikologi, masyarakat Palimanan umumnya petani dengan tingkat pendidikan rata-rata SD-SMP lebih memikirkan hal-hal yang bersifat instan, tidak terlalu peduli dengan program-program yang dianggap tidak dapat memenuhi kebutuhan dasar mereka. Pemahaman mereka terhadap kegiatan comrel penanaman jarak pagar pada lahan bekas galian tambang oleh PT. ITP dianggap "buang-buang” waktu saja dan hanya menguntungkan pihak perusahaan. Aplikasi program comrel di Palimanan, khususnya budidaya pohon jarak pagar adalah di lahanlahan bekas galian tambang dan lahan milik masyarakat. Lahan-lahan bekas galian tambang memiliki sifat keras dan tandus sehingga harus disuburkan kembali untuk bisa ditanami tanaman konsumtif seperti buah-buahan dan palawija, tetapi itu membutuhkan waktu yang sangat lama, Perusahaan memilih jarak pagar karena tanaman ini dapat tumbuh di lahan marginal, yaitu di lokasi pabrik dan lahan-lahan di quary.

Ada kesamaan pemahaman komunitas di Palimana dan Citeureup terbangun ketika perusahaan menggunakan konsep "green company" dalam merealisasikan berbagai program comrel. Hal ini membentuk mindset komunitas sehingga memiliki sikap yang khas, yaitu peduli kepada lingkungan berkelanjutan. 
Berbagai kebiasaan yang dilakukan seperti menghemat energi, menggunakan energi alternatif, melakukan kebiasaan "bersih", menggunakan produk ramah lingkungan dan ikut melestarikan lingkungan yang sehat. Semua ini program ini disosialisasikan melalui interaksi yang intens antara pihak perusahaan dan komunitas. Kegiatan community relations PT. Indocement di Palimanan dalam hal ini budidaya tanaman jarak pagar dan energy crops memang belum dapat memenuhi harapan mereka. Justru tuntutan yang menjadi harapan komunitas seperti uang debu dan pembagian sembako sebetulnya harapan jangka pendek saja, sedangkan perusahaan mengajak komunitas untuk program jangka panjang (sustainable).

Adapun dari wawancara dengan komunitas di Citeureup Bogor, diperoleh gambaran bahwa komunitas paham akan program comrel PT. Indocement. Hal ini disebabkan karena komunitas dilibatkan langsung dalam reklamasi dan revitalisasi lahan pasca tambang (P3M). Pendekatan teori konstruksi sosial dalam penelitian ini adalah mencoba menjelaskan bahwa latarbelakang budaya, situasi serta kondisi masyarakat atau komunitas sangat menentukan periaku. Komunitas Palimanan yang tinggal di desa-desa dengan mata pencaharian umumnya bertani, tentu berbeda dengan komunitas Citeureup yang umumnya berprofesi sebagai pedagang dan bengkel serta berlokasi dekat dengan kota metropolitan (Jakarta) namun dengan kegiatan sosialisasi tentang "green company" maka perbedaan itu dapat diatasi.

Pembahasan berikutnya melalui pendekatan Teori Etika Utilitarianisme, perusahaan mempertimbangkan nilai-nilai etika dalam mengambil sebuah keputusan, kebijaksanaan, untuk bertindak secara tepat yaitu memutuskan untuk melaksanakan comrel melalui program reklamasi dan revitalisasi lahan pasca tambang (marginal) melalui budidaya tanaman Jarak. Berkaitan dengan program reklamasi dan revitalisasi lahan melalui budidaya tanaman Jarak Pagar dan energy crops maka teori ini digunakan untk mengukur berapa banyak komunitas dan generasi ke depan yang akan dapat menikmati kehidupan lebih baik jika program ini di jalankan. Suatu program yang bertujuan baik tentu akan bisa dinikmati dan dirasakan kebaikan hasilnya bila menggunakan metode yang tepat.

Bagi suatu kegiatan bisnis yang baik maka etika utilitarianisme lebih menekankan pada long term net benefits, yaitu analisis keuntungan dan kerugian dalam jangka panjang, seperti membangun nama, reputasi, citra, brand yang kadang-kadang tampak merugikan (dalam jangka pendek). Aspek moral sangat berperan dalam bentuk kejujuran, mutu, pelayanan, disiplin dan semacamnya diharapkan akan 
muncul keunggulan perusahaan yang akan mendatangkan keuntungan, baik keuntungan dalam bentuk finansial, maupun keuntungan dalam bentuk nilai baik dan etis. Demikian halnya PT.Indocement yang melasanakan program comrel nya untuk jangka panjang dan jangka pendek bertujuan berbagi kebaikan kepada sebanyak mungkin komunitas.

\section{Perspektif Relationship Management} (John Ledingham dan Steven Bruning) menyatakan bahwa untuk menyeimbangkan kepentingan organisasi dengan publiknya perusahaan sebaiknya mengelola hubungan antara organisasi dan publik. Community relations yang dilaksanakan $\mathrm{PT}$. Indocement Tunggal Prakasa dilaksanakan dengan sungguh-sungguh, mulai dari penemuan fakta di lapangan, perencanaan, pelaksanaan hingga evaluasi. Dalam pengumpulan fakta selalu diawali dengan forum pertemuan dimana perusahaan melakukan interaksi yang efektif dengan komunitas melalui berbagai forum salah satunya Bilikom (Bina lingkungan dan komunikasi). Setiap program yang akan diluncurkan dibicarakan dalam forum, juga masukan-masukan warga. Pihak perusahaan berusaha memperoleh feedback sebanyakbanyaknya dari masyarakat guna mengevaluasi keberhasilan suatu program khususnya comrel.

Hubungan yang baik dengan komunitas telah menjadi dasar keberhasilan program comrel yang dilaksanakan perusahaan. Semua prasangka dan kekecewaan yang dikeluhkan komunitas berawal dari hubungan yang kurang intens antara perusahaan dengan komunitas. Teori ini memberi arah pada pengelola untuk menciptakan mutual understanding antara perusahaan dengan komunitas (stakeholder). Kesamaan pemahaman terhadap kegiatan program comrel dibangun berdasarkan konsep "green company", yaitu yang mendasari kegiatan comrel perusahaan dalam mengurangi berbagai dampak akibat kegiatan pertambangan baik di Palimanan maupun di Citeureup.

Dalam pelaksanaan program comrel PT. ITP terikat pada kode etik yang telah disepakati yaitu ISO 26000 (standar CSR Internasional), disamping itu perusahaan juga harus patuh pada berbagai aturan seperti perpem, perda, serta ketentuan perundang-undangan yang berlaku, berkaitan dengan ijin usaha, ijin eksplorasi serta ijin lainnya. Peran etika public relations berkaitan dengan nilai yang memberikan pedoman kepada seseorang, organisasi, atau masyarakat untuk membedakan antara benar dan yang salah, adil dan tidak adil, kejujuran dan kebohongan (Putra, 2019). Dalam berbagai kasus pertambangan misalnya realitas mendorong masyarakat untuk peduli terhadap berbagai dampak akibat kegiatan penambangan seperti kerusakan lingkungan, pencemaran air, udara serta hancurnya berbagai sumber 
kehidupan masyarakat. Sikap kritis disampaikan dalam berbagai forum formal maupun informal. Untuk kondisi ini PT. Indocement memiliki forum yaitu Bilikom. Masyarakat di Palimanan dan Citeureup seharusnya paham bahwa tujuan budidaya tanaman Jarak adalah merupakan itikad baik perusahaan untuk perbaikan kondisi lingkungan.

Etika berfungsi juga sebagai koridor agar masyarakat tertib, teratur taat norma dan saling menghargai demi kesehateraan bersama. Penerapan etika oleh perusahaan pertambangan diharapkan akan dapat mengurangi berbagai dampak buruk akibat kegiatan operasionalnya. Berbagai kegiatan community relations sebagai bentuk tanggungjawab yang dilaksanakan perusahaan diharapkan sunggung-sungguh dapat menciptakan kesejahteraan bersama, bukan hanya "basa-basi" saja. Komunitas Palimanan dan Citeureup seharusnya paham bahwa PT. Indocement melakukan community relations nya untuk menciptakan kondisi lebih baik. Demikian dari hasil dan analisa diatas telah diperoleh gambaran akan persamaan pemahaman komunitas terhadap kegiatan community relations perusahaan, baik di Palimanan maupun di Citeureup Bogor.

Gambar 1 menjelaskantentang terbentuknya kesamaan pemahaman terhadap kegiatan program comrel (energy crops, revitalisasi dan reklamasi) dibangun berdasarkan konsep

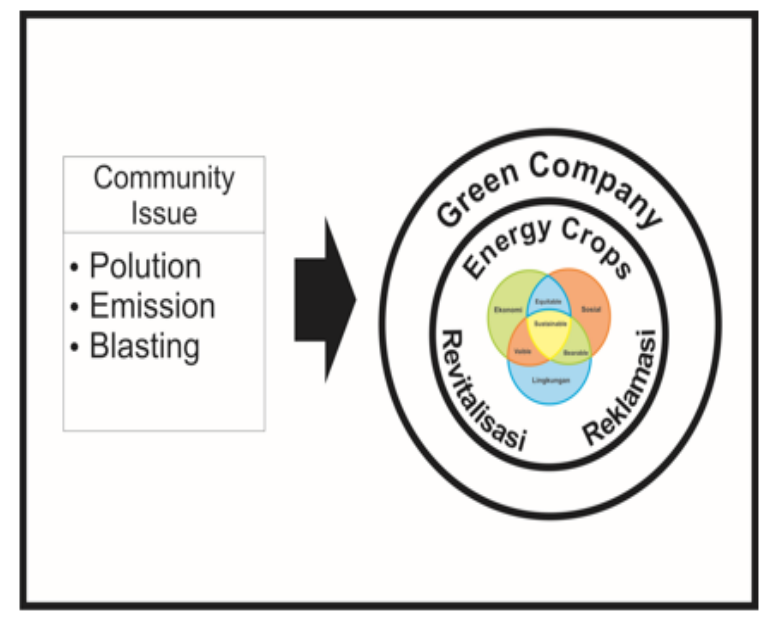

Sumber: Penelitian, 2013

Gambar 1 Model Pemahaman Komunitas

"green company". Konsep ini berkontribusi dalam mengurangi berbagai dampak akibat kegiatan pertambangan (polution, emission dan blasting), baik di Palimanan maupun di Citeureup.

\section{SIMPULAN}

Pemahaman Komunitas Palimanan terhadap program comrel di Palimanan adalah merupakan upaya yang lebih banyak menguntungkan pihak perusahaan. Masyarakat mendukung adanya upaya budidaya tanaman jarak sebagai energi alternatif yang lebih ramah lingkungan dan sebagai itikad baik perusahaan untuk perbaikan kondisi lingkungan. Sedangkan pemahaman komunitas Citeureup terhadap program comrel di Citeureup dipandang sebagai niat baik perusahaan.

Pemahaman komunitas terhadap kegiatan comrel PT. ITP melalui budidaya tanaman 
jarak pada lahan bekas galian tambang adalah bagaimana komunitas mengerti benar-benar akan keberadaan program ini. Pemahaman terjadi berdasarkan pengalaman dan pengetahuan komunitas mengenai situasi serta kondisi yang terjadi pada lingkungan sekitar akibat kegiatan produksi dari perusahaan. Sikap saling menghargai antara komunitas dan perusahaan didasari oleh penerapan etika sosial yang tepat. Dalam hal ini perusahaan menggulirkan program kepedulian terhadap lingkungan didasarkankan pada kepeduliannya akan kesejahteraan komunitas. Sikap etis perusahaan terhadap lingkungan, yaitu konsep Green Company yang mendasari program comrel PT Indocement Tunggal Prakasa pada akhirnya membentuk persamaan pemahaman komunitas baik di Palimanan maupun di Citeureup terhadap kegiatan comrel perusahaan.

\section{DAFTAR PUSTAKA}

Adiati, M. P. (2012). Program corporate social responsibility di industri hotel. Binus Business Review, 3(1), 502-512. https:// doi.org/https://doi.org/10.21512/bbr. v3i1.1338

Ardianto, E. (2010). Metodologi penelitian untuk public relations: Kuantitatif dan kualitatif. Bandung: Simbiosa Rekatama Media.

Creswell, J. W. (2013). Qualitative inquiry and research design: Choosing among five approaches (L. Habib (Ed.); 3rd Editio). SAGE Publications, Inc.
Devita, \& Sumartono. (2010). Hubungan manfaat kegiatan community relations dengan citra perusahaan PT. Indah Kiat Pulp \& Paper Tbk. pada masyarakat Kragilan Serang Banten. KOMUNIKOLOGI: Jurnal Ilmiah Ilmu Komunikasi, 7(2), 175-194. https://ejurnal.esaunggul.ac.id/index.php/ Kom/article/view/994

Garriga, E., \& Melé, D. (2004). Corporate Social Responsibility theories: Mapping the territory Social Responsibility Corporate theories: Mapping the territory. Journal of Business Ethics, 53, 51-71. https://doi. org/10.1787/9789264122352-de

Grunig, J. E., \& Hunt, T. T. (1984). Managing public relations. Holt, Rinehart and Winston.

Hartini, T. (2016). Strategi community relations lembaga pendidikan. Makna: Jurnal Kajian Komunikasi, Bahasa, Dan Budaya, 1(1), 33-43. https://doi.org/https://doi. org/10.33558/makna.v1i1.796

Haryono, D., Wisadirana, D., \& Chawa, A. F. (2018). Strategi pemberdayaan komunitas perempuan miskin berbasis agribisnis. Dimas: Jurnal Pemikiran Agama Untuk Pemberdayaan, 18(1), 1-18. https:// doi.org/http://dx.doi.org/10.21580/ dms.2018.181.2897

Iriantara, Y. (2010). Community relations: konsep dan aplikasnya. Bandung: Simbiosa Rekatama Media.

Isdarmanto. (2013). Pemberdayaan komunitas masyarakat bantaran Kali Code dalam mewujudkan kawasan desa wisata yang berbasis budaya. Kepariwisataan: Jurnal Ilmiah, 7(3), 51-70. http://ejournal. stipram.ac.id/index.php/kepariwisataan/ article/view/168

Karmini. (2019). Strategi peningkatan investasi non tambang di Kabupaten Kutai 
Kartanegara. Jurnal Riset Pembangunan, 1(2), 71-78. https://doi.org/10.36087/jrp. v1i2.36

Kuswarno, E. (2009). Fenomenologi: Konsep, pedoman dan contoh penelitian. Bandung: Widya Padjadjaran.

Putra, D. K. S. (2019). Komunikasi CSR politik: membangun reputasi, etika, dan estetika PR politik. Jakarta: Prenada Media.

Putri, N. E., Hakim, N., \& Yamin, M. (2016). Ecologicall footprint and biocapacity analysis for flooding prevention in South Sumatera. Jurnal Mimbar, 32(1), 58-64.

Resdiana, E., \& Widyastuti, E. (2019). Tanggung jawab sosial perusahaan dari perspektif komunitas di Kecamatan Gili Genting Sumenep. Performance, 9(1), 55-63.

Salim,A.(2016). Teoridan paradigmapenelitian sosial, buku sumber untuk penelitian kualitatif edisi kedua. Yogyakarta: Tiara Wacana.

Siregar, B. (2016). Memaksimalkan citra perusahaan melalui implementasi Corporate Social Responsibility. At-Tijaroh: Jurnal Ilmu Manajemen Dan Bisnis Islam, 2(1), 27-41. https://doi.org/https://doi. org/10.24952/at-tijaroh.v2i1.786

Siwi, M. (2017). Kontestasi pengetahuan negara, swasta dan masyarakat dalam pengelolaan program Corporate Social Responsibility. Jurnal Sains Komunikasi Dan Pengembangan Masyarakat [JSKPM], l(1), 115-128. https://doi.org/10.29244/ jskpm.1.1.115-128

Sonny, K. (1998). Etika bisnis tuntutan dan relevansinya. Jakarta: Kanisius.

Sujarwani, R., Wulandari, F. D., Husni, A., \& Rianto, F. (2018). Pemberdayaan Masyarakat Komunitas Aadat Terpencil
(KAT) oleh pemerintah Kabupaten Lingga. Jurnal Antropologi: Isu-Isu Sosial Budaya, 20(1), 17-31. https://doi.org/https://doi. org/10.25077/jantro.v20.n1.p17-31.2018

Suparman. (2013). Coorporate Social Responsibility: Bentuk tanggung jawab sosial dan kepedulian perusahaan dengan masyarakat. Interaksi: Jurnal Ilmu Komunikasi, 2(2), 172-184. https://doi.org/https://doi.org/10.14710/ interaksi.2.2.172-184

Triyono, A. (2014). Pemberdayaan masyarakat melalui community development program Posdaya (Pos Pemberdayaan Keluarga) PT. Holcim Indonesia Tbk pabrik Cilacap. Komuniti: Jurnal Komunikasi Dan Teknologi Informasi, 6(2), 111-121. https:// doi.org/https://doi.org/10.23917/komuniti. v6i2.2949

Umma, E., Hafiar, H., \& Priyatna, C. C. (2016). Model kemitraan di PT. Holcim Indonesia, Tbk. PRofesi Humas - Jurnal Ilmiah Program Studi Hubungan Masyarakat, 1(1), 22-34. https://doi.org/https://doi. org/10.24198/prh.v1i1.9468

Wibisono, S. G. (2018). Pertambangan di Kaltim di antara kerusakan lingkungan dan persawahan. Beritagar.id. https:// beritagar.id/artikel/berita/pertambangandi-kaltim-di-antara-kerusakan-lingkungandan-persawahan

Yin, R. K. (2014). Studi kasus desain \& metode. Jakarta: Rajawali Press.

Yusuf, Y. M., Prastyo, D. A., Khaerunnisa, L., \& Raharjo, S. T. (2020). Implementasi program Corporate Social Responsibility oleh perusahaan unicorn di Indonesia. Prosiding Penelitian Dan Pengabdian Kepada Masyarakat, 6(3), 252-258. 